\title{
Effects of Patientand Physioterapist Characteristics on Perceived Quality of Physiotherapy Care at Dr. Moewardi Hospital, Surakarta
}

\author{
Afif Ghufroni',2), Rita Benya Adriani'), Didik Tamtomo') \\ 1)Masters Program on Public Health, Universitas Sebelas Maret \\ 2)School of Health Polytechnics Surakarta
}

\begin{abstract}
Background: Nowadays patients demand quality and safe hospital care. Quality of care depends on the roles of the government as quality of care regulator, hospital management, health care providers, patients, and the community. This study aimed to examine the effects of patient and physioterapist characteristics on perceived quality of physiotherapy care.

Subjects and Method:This was an observational analytic study with cross-sectional design. The study was conducted at Dr. Moewardi Hospital, Surakarta, Central Java, from June to July, 2017. A total sample of 122 physiotherapy patients were selected for this study using exhaustive sampling. The dependent variable was quality of physiotherapy care. The independent variables were education, income, duration of treatment, insurance status, years of service, physiotherapist training, and salary. The data were collected using a set of questionnaire and analyzed by multiple linier regression.

Results: The quality of physiotherapist care was affected by patient's income $(b=-0.18 ; 95 \% \mathrm{CI}=-$ 0.35 to $0.001 ; \mathrm{p}=0.052)$, patients education $(\mathrm{b}=-3.32 ; 95 \% \mathrm{CI}=-6.59$ to $0.04 ; \mathrm{p}=0.047)$, duration of treatment $(\mathrm{b}=-0.07 ; 95 \% \mathrm{CI}=-0.14$ to $-0.01 ; \mathrm{p}=0.020)$, insurance status $(\mathrm{b}=3.41 ; 95 \% \mathrm{CI}=0.15$ to $6.68 ; \mathrm{p}=0.041)$, years of services $(\mathrm{b}=0.55 ; 95 \% \mathrm{CI}=0.15$ to $0.97 ; \mathrm{p}=0.010)$, physiotherapist training $(\mathrm{b}=0.90 ; 95 \% \mathrm{CI}=0.09$ to $1.71 ; \mathrm{p}=0.030)$, and salary $(\mathrm{b}=0.38 ; 95 \% \mathrm{CI}=-0.12$ to $0.77 ; \mathrm{p}=$ 0.061).
\end{abstract}

Conclusion:Quality of physiotherapist care is affected by patient's income, patients education, duration of treatment, insurance status, years of services, physiotherapist training, and salary.

Keywords:quality of care, physiotherapy, insurance status, duration of treatment, years of services

\section{Correspondence:}

Afif Ghufroni. School of Health Polytechnics, Surakarta, Central Java. Email: apip.physio@gmail.com. Mobile: +6285725000769 .

\section{BACKGROUND}

Physiotherapy is a healthcare provided to individuals and or groups to develop, maintain and restore body movements and functions throughout the life cycle by using manual handling, increased motion, equipment (physical, electrotherapeutic, and mechanical), function training, communication (Regulation of the Minister of Health, 2013). The Indonesian Physiotherapy Association as a professional organization has made various efforts to guarantee the quality of physiotherapy services (Imron, 2016). Law number 80 of 2013 contains the standards of physiotherapy services that regulate physiotherapy services should be given to the healthcare. The Indonesian physiotherapy association issued the latest clinical practice guidebook in February 2017. The existing regulations have not reflected quality physiotherapy care (Imron, 2016).

Based on the health profile of Central Java in 2015, all hospitals in Surakarta did 
Journal of Health Policy and Management (2017), 2(1): 69-80

https://doi.org/10.26911/thejhpm.2017.02.01.06

not report the progress of achieving quality of healthcare in each hospital including the Dr. Moewardi Hospital, Surakarta, so that the quality of the healthcare provided could not be seen. However, based on the report on the quality indicator of the medical rehabilitation installation at Dr. Moewardi Hospital, Surakarta, from November 2015 to August 2016, the quality of care in medical rehabilitation did not achieved the target by 90\%, even though it showed an increase every month (Dr. Moewardi Hospital, 2016).

Factors that affect perceived quality of physiotherapy care are family income, education level, duration of treatment, insurance status, physiotherapist training, physiotherapist training, and physiotherapist salary.

Patient income affects the quality of care received by patients. Family income is the amount of real income from all members of the household received from main income, extra income, and other income (Nuralamet al, 2015). Low family income affect on the inability to buy drugs, pay for transportation, and others, so that an individual is not able to use the healthcare (Sutrisna, 1994). On the contrary, high family income will provide opportunities to obtain good nutrition and good healthcare (Suryati, 2005).

The different education level of patient affect the assessment of quality of healthcare. Education level is the stage of education which is determined based on the level of development of students, goals, and capabilities developed (Law on National Education System Number 20, 2003). The different levels of patient education visiting healthcare affect on the different assessments of quality of care. Patients with a low education level are satisfied with the services provided. However, patients with higher education level will give lower assessment.

The duration of treatment received by the patient affects the assessment of healthcare. Duration of treatment is one of the success factors of health services to achieve good service (Revans, 2004; Wartawan, 2012). Many theories state that there is a correlation between duration of treatment of patients and patient satisfaction as an illustration of the quality of care. The increasing number of visits or treatments of patients will increase the patient understanding of the quality of health care (Wartawan, 2012; Barbara, 2006; Chriswardani, 2006).

The insurance status carried out by patients affects the service received. Payment method is an important part which affect the good or bad quality of health care; it will affect the behavior patterns of health services itself (Agyeponget al., 2014). Various types of payment methods have an effect on the behavior of healthcare workers, so that they can affect the good or bad quality of health services (Trisnantoro, 2007). Nowadays, there are two payment methods on healthcare: National Health Insurance Implementing Agency (BPJS) and payment independently. There are differences in health services received through these payment methods.

Work experience affects the provision of quality of health care. As an illustration, an physiotherapist who works longer will be more skilled in providing services. Dr. Moewardi Hospital in Surakarta has 19 physiotherapists with more than 20 years of experience. The longer the years of service of a health worker, the more knowledge and skills increase, so that it can increase the quality of care (Kim et al., 2017).

The training conducted by the Indonesian Physiotherapy Association (IFI) has increased lately. Based on the IFI data, 
every month, there were 10 physiotherapy training activities, so that there were more than 100 trainings in one year. However, the participation of physiotherapist in the training did not aim to develop knowledge that would affect the quality of care in patients. There were many physiotherapists attended the training just to extend the registration letter (Imron, 2016).

Related to the salary, every employee at the Dr Moewardi Hospital in Surakarta gets an average income each month in excess of the minimum wage. Based on Central Java Governor Decree Number 560/50/2016 concerning minimum wages in 35 Provincies/Regencies in Central Java 2017 on November 21, 2016, the minimum wage in Surakarta is Rp 1,534,985.

Based on a study conducted by Zarei et al., (2012) in Iran, service quality (SERVQUAL) is measuring instrument for a valid, reliable, and flexible quality of care. SERVQUAL method is a measuring instrument which will be used to measure quality of care that has been widely applied and developed (Parasuraman et al., 1985; Zeithaml et al., 1990). SERVQUAL consists of 5 elements, such as tangibles, reliability, responsiveness, assurance, and empathy (Vanet al., 2003). SERVQUAL is a measurement instrument that is often used in measuring the quality of health care to service users (Gronroos, 1982; Lewis and boom, 1983; Parasuramanet al., 1985).$$
\text { SUBJECTS DAN METHOD }
$$

1. study Design

This was an analytic observational study with a cross-sectional design which focused on the process of data collection of independent and dependent variables which conducted two times with different times. The use of the design aimed to examine the effects of patient and physiotherapist characteristics on perceived quality of
}

physiotherapy care in Dr. Moewardi Hospital, Surakarta.

\section{Place and time of the study}

This study conducted in the physiotherapy clinic of Dr. Moewardi Hospital, Surakarta, from June to July, 2017.

\section{Population dan samples}

The target population in this study was 720 patients who visited physiotherapy clinic and physiotherapists who worked in Dr. Moewardi Hospital, Surakarta.

The accessible population in this study was 720 patients who visited physiotherapy clinic at Dr. Moewardi Hospital, Surakarta.

This study used formula of independent variables multiplied by $\mathbf{1 5 - 2 0}$ (Murti, 2013). There were 7 free variables in this study. There were 105-140 samples as the subjects of the study which was found from the free variables. There were 122 people as the subjects of the study.

\section{Sampling Technique}

This study used exhaustive sampling using non-random sampling. The researcher took all subjects from the source population as samples to study (Bhisma, 2010). The samples were all patients who visited the physiotherapy clinic of Dr. Moewardi Hospital, Surakarta, and did therapy in June-July 2017.

\section{Study Variables}

The independent variables were patient income, patient education level, duration of treatment, insurance status, years of services, physiotherapist training, and physiotherapist salary. The dependent variable was quality of health care.

\section{Operational Definition}

Education level was the latest formal education level that has been taken by patients based on the last diploma they had.

Family income was income that was in the form of money or in other forms that could be cashed from the work carried out 
Journal of Health Policy and Management (2017), 2(1): 69-80

https://doi.org/10.26911/thejhpm.2017.02.01.06

by family members, which were in line with the minimum wage in Surakarta.

Insurance status was the payment method for physiotherapy care which have been received.

Duration of treatment was how long the treatment carried out by outpatients to physiotherapy care at Dr. Moewardi Hospital, Surakarta.

Work experience of the physiotherapist was the period of time of work experience as a physiotherapist since the first time he worked at the hospital.

Physiotherapist training was the training attended by the physiotherapist for the past 5 years.

Physiotherapist salary was the income received by the physiotherapist every month based on the minimum wage in Surakarta.

Quality of care was the gap between expectations expected by patients on the services provided by physiotherapists.

\section{Study subjects}

The subjects of this study were outpatients in the physiotherapy clinic at Dr. Moewardi Hospital in Surakarta. The inclusion criteria of this study were all patients who did therapy at the physiotherapy clinic Dr.
Moewardi, Surakarta, and willing to be the subjects of this study.

\section{Instrument of the study}

The data of this study were carried out observationally on the health care users conducted directly by the researchers.

Questionnaires were given to the patients to obtain an overview of the services felt by the patients. Secondary data were obtained from the hospital's education and training section, the previous study, and related references. Secondary data were the number of visits and hospital profiles.

Quality of care was assessed using service quality questionnaire with 5 dimensions of measurement namely tangibles, reliability, responsiveness, assurance, and empathy. Afterwards, the effects of quality of care on the patient personal factors such as patient income, education level, duration of treatment, physiotherapist status and personality in the form of physiotherapist years of service, physiotherapist training, and physiotherapist salary could be analyzed. The reliability test of the questionnaires has been carried out previously on the 20 outpatients who visited physiotherapy clinic.

Table 1. The result of the reliability test of the questionnaires on quality of care as variable

\begin{tabular}{clcc}
\hline No & \multicolumn{1}{c}{ Variables } & Cronbach's Alpha & Decision \\
\hline 1 & Tangible & 0.78 & Reliable \\
2 & Reliability & 0.96 & Reliable \\
3 & Responsiveness & 0.91 & Reliable \\
4 & Assurance & 0.84 & Reliable \\
5 & Empathy & 0.90 & Reliable \\
\hline
\end{tabular}

\section{RESULTS}

The result of the characteristics of the subjects of the study showed that 115 outpatients as subjects of the study at Dr. Moewardi Hospital aged $\geq 50$ years
(94.3\%). 95 out of 122 subjects of the study were female (77.9\%). 63 patients were educated more or equal to senior high school (51.6\%) and 96 patients were retirees and housewives (78.7\%). 72 patients had $\geq$ minimum wage (56.9\%). 
Ghufroni et al./ Effects of Patient and Physioterapist Characteristics

Table 2. The descriptive data of the variable of the study

\begin{tabular}{lcccc}
\hline \multicolumn{1}{c}{ Variables } & Min. & Max. & Mean & SD \\
\hline Patient Income & 3 & 40 & 20.72 & 9.62 \\
Duration of Treatment & 1 & 102 & 27.43 & 23.93 \\
Physiotherapist Salary & 37 & 50 & 44.17 & 3.82 \\
Physiotherapist Training & $\mathrm{O}$ & 5 & 2.08 & 1.86 \\
Physiotherapist years of service & 12 & 32 & 24.11 & 3.58 \\
Quality of Care & 120 & 165 & 149.52 & 9.32 \\
\hline
\end{tabular}

Table 2 shows the descriptive statistics of each exogenous and endogenous variable such as minimum, maximum, mean, and standard deviation. The variable of patient income had an average value by 20.72 (Rp. 2,072,000) with a standard deviation by 9.62 (Rp. 962,000), a minimum value by 3 (Rp. 300,000), and a maximum value by 40 (Rp. 4,000,000). The high standard deviation (more than $30 \%$ of the mean) showed the high variety of variations, or the big gap between the lowest and highest patient income scores.

The variable of duration of treatment had an average value by27.43 (month) with a standard deviation by23.93 (month), a minimum value by1 (month), and a maximum value by 102 (month). The low standard deviation (less than $30 \%$ of the mean) showed the low variety of variations, or the small gap between the lowest and highest duration of treatment.

The variable of physiotherapist salary had an average value by 44.17 (Rp 4,417,000) with a standard deviation by 3.82 (Rp 382,000), a minimum value by 37 ( $\mathrm{Rp} 3,700,000)$, and a maximum value by 50 (Rp 5,000,000). The low standard deviation (less than $30 \%$ of the mean) showed the low variety of variations, or the small gap between the lowest and highest physiotherapist salary.

The variable of physiotherapist training had an average value by 2.08 with a standard deviation by 1.86 (times), a minimum value by 0 , and a maximum value by
5. The high standard deviation (more than $30 \%$ of the mean) showed the high variety of variations, or the big gap between the lowest and highest physiotherapist training.

The variable of physiotherapist years of service had an average value by 24.11 (year) with a standard deviation by 3.58 (year), a minimum value by 12 (year), and a maximum value by 32 (year). The low standard deviation (less than 30\% of the mean) showed the low variety of variations, or the small gap between the lowest and highest physiotherapist years of service.

The variable of quality of care had an average value by 149.52 with a standard deviation by 9.32 , a minimum value by 120 , and a maximum value by 165 . The low standard deviation (less than 30\% of the mean) showed the low variety of variations, or the small gap between the lowest and highest quality of care scores.

\section{Bivariate analysis}

Table 3. The bivariate analysis of factors associated with on perceived of quality of physiotherapy care

\begin{tabular}{lcc}
\hline \multicolumn{1}{c}{ Variables } & $\mathbf{r}$ & $\mathbf{p}$ \\
\hline Patient income & -0.26 & 0.004 \\
Education level & -0.29 & 0.001 \\
Duration of treatment & -0.27 & 0.002 \\
Insurance status & 0.07 & 0.428 \\
Physiotherapist years of & 0.25 & 0.006 \\
service & & \\
Physiotherapist training & 0.16 & 0.072 \\
Physiotherapist salary & 0.21 & 0.020 \\
\hline
\end{tabular}


Journal of Health Policy and Management (2017), 2(1): 69-80

https://doi.org/10.26911/thejhpm.2017.02.01.06

There was a negative effect of patient income on perceived quality of physiotherapy care. The higher the patient income, the lower the assessment of perceived quality of physiotherapy care $(\mathrm{r}=-0.26 ; \mathrm{p}=$ 0.004).

There was a negative effect of education level on perceived quality of physiotherapy care. The higher the education level, the lower the assessment of perceived quality of physiotherapy care $(\mathrm{r}=-0.29 ; \mathrm{p}=$ 0.001).

There was a negative effect of duration of treatment on perceived quality of physiotherapy care. The longer the duration of treatment, the lower the assessment of perceived quality of physiotherapy care( $\mathrm{r}=$ $0.27 ; \mathrm{p}=0.002$ ).

There was a positive effect of insurance status on perceived quality of physiotherapy care. The higher the insurance status, the higher the perceived quality of physiotherapy care $(r=0.07 ; p=0.428)$.

There was a positive effect of physiotherapist years of service on perceived quality of physiotherapy care. The longer the physiotherapist years of service, the higher the perceived quality of physiotherapy care $(\mathrm{r}=0.25 ; \mathrm{p}=0.006)$.

There was a positive effect of physiotherapist training on perceived quality of physiotherapy care. The more often the physiotherapist training conducted, the higher the perceived quality of physiotherapy care $(r=0.16 ; p=0.072)$.

There was a positive effect of physiotherapist salary on perceived quality of physiotherapy care. The higher the physiotherapist salary received, the higher the perceived quality of physiotherapy care $(\mathrm{r}=$ $0.21 ; p=0.020$ ).

\section{Multivariate analysis}

The patient income affected the decrease in the assessment of perceived quality of physiotherapy care which was statistically significant. Each increase of one point of patient income decreased 0.18 points of perceived quality of physiotherapy care $(b=$ -0.18; 95\% CI $=-0.35$ to <0.001; $\mathrm{p}=0.052$ ).

The education level affected the decrease in the assessment of perceived quality of physiotherapy care which was statistically significant. Each increase of one point of education level decreased 3.32 points of perceived quality of physiotherapy care $(b=-3.32 ; 95 \% C I=-6.59$ to $0.04 ; p=$ 0.047).

The duration of treatment affected the decrease in the assessment of perceived quality of physiotherapy care which was statistically significant. Each increase of one point of duration of treatment decreased 0.07 points of perceived quality of physiotherapy care $(\mathrm{b}=-0.07 ; 95 \% \mathrm{CI}=$ 0.14 to $-0.01 ; \mathrm{p}=0.020$ ).

The insurance status affected the increase in the assessment of perceived quality of physiotherapy care which was statistically significant. Each increase of one point of insurance status increased 3.41 points of perceived quality of physiotherapy care $(b=3.41 ; 95 \% \mathrm{CI}=0.15$ to $6.68 ; \mathrm{p}=$ 0.041).

The physiotherapist years of service affected the increase in the assessment of perceived quality of physiotherapy care which was statistically significant. Each increase of one point of physiotherapist years of service increased 0.55 points of perceived quality of physiotherapy care $(b=$ $0.55 ; 95 \% \mathrm{CI}=0.15$ to $0.97 ; \mathrm{p}=0.010$ ).

The physiotherapist training affected the increase in the assessment of perceived quality of physiotherapy care which was statistically significant. Each increase of one point of physiotherapist training increased 0.90 points of perceived quality of physiotherapy care $(b=0.90 ; 95 \% \mathrm{CI}=$ 0.09 to $1.71 ; \mathrm{p}=0.030$ ). 
The physiotherapist salary affected the increase in the assessment of perceived quality of physiotherapy care which was statistically close to significant. Each increase of one point of physiotherapist salary increased 0.38 points of perceived quality of physiotherapy care $(\mathrm{b}=0.38 ; 95 \%$ $\mathrm{CI}=-0.12$ to $0.77 ; \mathrm{p}=0.061$ ).

Table 4. The result of the analysis of multiple linear regression of patient personal and physiotherapist factors on perceived quality of physiotherapy care at Dr. Moewardi Hospital, Surakarta

\begin{tabular}{|c|c|c|c|c|}
\hline \multirow{2}{*}{ Independent Variables } & \multirow{2}{*}{ b } & \multicolumn{2}{|c|}{$95 \% \mathrm{CI}$} & \multirow{2}{*}{$\mathbf{p}$} \\
\hline & & Lower Limit & Upper Limit & \\
\hline Constant & & 101.17 & 144.49 & $<0.001$ \\
\hline Family income & -0.18 & -0.35 & 0.00 & 0.052 \\
\hline Education level & $-3 \cdot 32$ & -6.59 & -0.04 & 0.047 \\
\hline Duration of treatment & -0.07 & -0.14 & -0.01 & 0.020 \\
\hline Insurance status & 3.41 & 0.15 & 6.68 & 0.041 \\
\hline Physiotherapist years of service & 0.55 & 0.13 & 0.97 & 0.010 \\
\hline Physiotherapist training & 0.90 & 0.09 & 1.71 & 0.030 \\
\hline Physiotherapist salary & 0.38 & -0.02 & 0.77 & 0.061 \\
\hline $\begin{array}{l}\text { Number of subjects } n=122 \\
p<0.001\end{array}$ & & & & \\
\hline
\end{tabular}

\section{DISCUSSION \\ A.The effect of family income on perceived quality of physiotherapy care}

The result of the analysis of multiple linear regression indicated that there was a negative effect between family income and perceived quality of physiotherapy care. Family income affected the decrease in the assessment of perceived quality of physiotherapy care which was statistically significant. The higher the family income, the lower the assessment of perceived quality of physiotherapy care received.

Based on a study conducted by Olaleye et al., (2015), poor patient families with children with cerebral palsy feel the quality of physiotherapy care more than rich families. Poor families indicate low family income therefore they consider that they obtain higher quality of service. In addition, high-income patients have higher requirements toward health service (Khuong et al., 2013). When the health care providers cannot provide services in accordance with patient expectations, patients tend to have low assessment on the quality of care. Service requirements in order to cure patient that cannot be fulfilled by the hospital will lead to the low quality of care (Dengjuin et al., 2009).

Based on a study conducted by Kawachi et al. (2010), income and wealth are used to achieve better health. A community that has low income tend to unable to choose the quality of a health care. Meanwhile, high income groups will choose good quality standards to get healing (Braveman et al., 2011).

\section{B. The effect of education level on perceived quality of physiotherapy care}

The result of the analysis of multiple linear regression indicated that there was a negative effect between education level and perceived quality of physiotherapy care. The patient education level affected the decrease in the assessment of perceived quality of physiotherapy care which was statistically significant. The higher the 
Journal of Health Policy and Management (2017), 2(1): 69-80

https://doi.org/10.26911/thejhpm.2017.02.01.06

patient education level, the lower the assessment of perceived quality of physiotherapy care received.

This study is in line with a study conducted by Almeida et al., (2013) in the physiotherapy department which state that the higher the education level, the lower the assessment of perceived quality of physiotherapy care

Based on a study conducted in Turkey (Bakar et al., 2008) and Taiwan (Dengjuin et al., 2009), patients with higher education level have higher hopes and desires on perceived quality of health care received compared to patients with low income. Based on a study conducted by Fraihi et al., (2016), high expectations affect the low assessment given by the patients on quality of care. Conversely, patients with low expectations would be easy to receive the services provided for healing. As a result, patients tend to give high assessment on the quality of care.

This study is supported by a study conducted by Mulisa et al., (2017) that patients who visit radiology care with higher education tend to give lower quality of care scores than those with lower education. Another study by Fletchera and Frisvol (2012) state that higher education affects various types of medical actions. The higher the patient education level, the higher the desire, hope, and trust of the patient/family of the patient toward all medical treatment. For the patient safety and healing, patient with high education level will think critically and has higher demands. Therefore, if a patient is not pleased with the medical treatment taken by the medical team, the patient can reject the medical treatment. Meanwhile, a patient with low education level tend to accept the treatment given for healing. Patient with low education level feel that the quality of care provided is better than those with higher education.

\section{The effect of duration of treatment on perceived quality of physio- therapy care}

The result of the analysis of multiple linear regression indicated that there was a negative effect between duration of treatment and perceived quality of physiotherapy care. The duration of treatment affected the decrease in the assessment of perceived quality of physiotherapy care which was statistically significant. The longer the duration of treatment, the lower the assessment of perceived quality of physiotherapy care received.

Based on a study conducted by Sarwar et al., (2014), outpatients prefer to visit the hospital by considering the cost, quality of care, type of care and availability of care provided.Good quality of care will shorten the treatment given to patients, so that patients with long duration of treatment will tend to give low assessment on the quality of care. Another study conducted by Mulisa et al., (2017) state that patients with too long waiting time to enter the radiological examination room show a low assessment of quality of care compared to those with short waiting time.

This study is supported by Guptaet al., (2012) about the level of quality received by cancer patients on the mortality rate of cancer patients show thatpatients with high quality of care experience will likely to have far lower mortality rate than patients with low quality of care experience. Based on this study, good quality of care affects the result of the treatment. The good result of treatment will shorten the duration of treatment. 


\section{D.The effect of insurance status on perceived quality of physiotherapy care}

The result of the analysis of multiple linear regression indicated that there was a positive effect between insurance status and perceived quality of physiotherapy care. The insurance status affected the increase in the assessment of perceived quality of physiotherapy care which was statistically significant.

The use of health insurance still becomes a contradicton to the quality of care received by patients. The users of BPJS PBI (Premium Assistance Recipients of National Health Insurance Implementing Agency) should be able to use the opportunity to seek treatment without distinguishing quality of health care. The perceptions of BPJS users on quality of care provided affect the use of BPJS in doing treatment (Rumengan et al., 2015). Providing different services from service providers between BPJS PBI insurance users and BPJS Non-PBI will lead to different assessment between BPJS PBI and BPJS Non-PBI. BPJS PBI users will give low assessment to the quality of health care. Otherwise, BPJS Non-PBI users will give higher assessment to the quality of health care because they get special treatment compared to PBI BPJS users. Patients who use BPJS Non-PBI insurance have higher expectations due to the monthly obligations to pay premiums have been fulfilled (Mulyani, 2017). Meanwhile, BPJS PBI users tend to receive services provided because they are not burdened by the obligation to pay premiums every month.

\section{E. The effect of physiotherapy work experience on perceived quality of physiotherapy care}

The result of the analysis of multiple linear regression indicated that there was a positive effect between physiotherapist years of service and perceived quality of physiotherapy care. The physiotherapist years of service affected the increase in the assessment of perceived quality of physiotherapy care which was statistically significant. The more experienced a physiotherapist is, the higher the value of the quality of care provided to the patients.

A study conducted by Schembri (2014) about the experience of patients handled by good equipments and carried out deftly shows the high assessment of perceived quality of physiotherapy care. A skilled physiotherapist will provide therapy to patients deftly. As a result, patients who are handled by skilled physiotherapists will tend to give high assessment on the quality of care.

According to Kim et al., (2017), the longer the years of service of health workers, the more skilled and knowledgeable the health workers. Patients will feel satisfied if they are handled by skilled and knowledgeable health workers. According to Krishnamy et al., (2001), communication skills are very important to provide quality services. This communication is considered as an important thing, especially to patients who have degenerative diseases. The information delivered to them is useful to determine the complexity of the disease, the certainty of the patient recovery and the treatments taken to deal with the problem. Good communication uses a language that is easily understood by patients, so that the information is delivered clearly (Herqutanto et al, 2011).

\section{F. The effect of physiotherapist train- ing on perceived quality of physio- therapy care}

The result of the analysis of multiple linear regression indicated that there was a positive effect between physiotherapist training and perceived quality of physiotherapy care. The physiotherapist training affected 
Journal of Health Policy and Management (2017), 2(1): 69-80

https://doi.org/10.26911/thejhpm.2017.02.01.06

the increase in the assessment of perceived quality of physiotherapy care which was statistically significant. The more often a physiotherapist participated in the training, the higher the quality of care.

Based on a study conducted by Hasmoko (2008), one of the factors which affect the performance of health workers is the improvement of clinical skills through further education, training, and seminars. Before doing training, it is better to do a pre-test and post-test to see the improvement of the clinical skills. Increased clinical skills will affect the quality of care. This study is supported by a study conducted by Handayani et al., (2009) that factors which are considered important in improving the performance of health workers in continuous learning are training and seminars.

\section{G. The effect of physiotherapist salary on perceived quality of physio- therapy care}

The result of the analysis of multiple linear regression indicated that there was a positive effect between physiotherapist salary and perceived quality of physiotherapy care. The physiotherapist salary affected the increase of perceived quality of physiotherapy care which was statistically close to significant.

Based on a study conducted by Bardach et al., (2014), the salary of health workers received is very effective in improving the quality of the performance of health workers to the fullest. The good performance of health workers plays an active role in improving healing outcomes, so that it will improve the quality of care provided. According to Roland and Dudley (2015) the enhancing incentives will affect the performance quality of health workers in providing services.

\section{REFERENCES}

Agyepong IA, Aryeetey GC, Nonvignon J, Boadi FA, Dzikunu H, Antwi E, Ankrah D (2014). Advancing the application of systems thinking in health: provider payment and service supply behaviour and incentives in the Ghana National Health Insurance Scheme - a systems approach. Health Research Policy and Systems: 12:35.

Almeida RS, Nogueira LA, BourliatauxLajoine S. (2013). Analysis of the user satisfaction level in a public physical therapy service. National Center for Biotechnology Information. DOI: 10.1590/S1413-35552013005000097

Bakan I, Buyukbese T, Ersahan B. (2013). The impact of total quality service (TQS) on healthcare and patient satisfaction: An empirical study of Turkish private and public hospitals. The International Journal of Health Planning And Management Int J Health Plann Mgmt: 29: 292-315. DOI: 10.1002/-hpm.2169.

Bakar C, Akgün HS, Al Assaf A (2008): The role of expectations in patients' hospital assessments: A Turkish university hospital example. Int $\mathrm{J}$ Health Care Qual Assur. 21: 503-516. Doi: 10.1108/09526860810890477.

Barbara J, Billie F, Pendit B (2006). Buku Ajar Perawatan Perioperatif. Kedokteran EGC. Cetakan I. Jakarta.

Braveman P, Egerter S, Barclay C (2011). Exploring The Social Determinants Of Health. Robert Wood Johnson Foundation Commission To Build A Healthier America. 12: 4.

Chriswardani S (2006). Penyusunan Indikator Kepuasan Pasien Rawat Inap Rumah Sakit di Provinsi Jawa Tengah. Jurnal Managemen Pelayanan Kesehatan. 
Dengjuin L, YaHsin L, JarYuan P, IngCheau S, Glen R, MingJen C (2009): Chronic kidney-disease screening service quality: questionnaire survey research evidence from Taichung City. BMC Health Serv Res. 9: 239-10. Doi: 1186/1472-6963-9-239.

Eygen LV, Lerberghe V, Blaise P, Woelk G, Criel B (2006). The Challenge of Measuring Quality of Care at Health Centre Level in Africa: the Example of Tsholotsho Health District in Matabeleland North, Zimbabwe.International Journal of Health Planning and Management: 22: 63-89. DOI: 10.1002/hpm.859.

Fletchera JM, Frisvol DE (2012). Higher Education and Health Investments: Does More Schooling Affect Preventive Health Care Use?. (2): 144-176. doi: 10.1086/645090.

Fraihi KJA, Famco D, Famci F, Latif SA (2016). Evaluation of outpatient service quality in Eastern Saudi Arabia Patient's expectations and perceptions. Saudi Med J.37(4): 420-428. doi: 10.15537/smj.2016.4.14835.

Gupta D, Lis CG, Rodeghier M. (2012). Can patient experience with service quality predict survival in colorectal cancer?. US National Library of Medicine National Institutes of Health. DOI: 10.1111/j.1945-1474.2012.00217.x

Handayani L dan Sopacua E.(2009). Peran tenaga kesehatan sebagai pelaksana pelayanan kesehatan puskesmas. Buletin Penelitian Sistem Kesehatan. 13(1): 12-20.

Hasmoko EV (2008). Analisis faktor-faktor yang mempengaruhi Kinerja klinis perawat berdasarkan penerapan Sistem pengembangan manajemen kinerja klinis (spmkk) di ruang rawat inap Rumah sakit panti wilasa cita- rum semarang. Program Pascasarjana Uni-versitas Diponegoro Semarang.

Imron A (2016). Peningkatan Kapasitas core competency pada prodi fisioterapi dalam inisiasi performance assessment (penilaian kerja) fisioterapi muskuloskeletal. Pusat pendidikan sumberdaya manusia kesehatan kementrian kesehatan republik indonesia. Ikatan Fisioterapi Indonesia. Bali.

Kim CU, Shin JS, Lee J, Lee YJ, Kim M, Choi A, Park KB (2017). Quality of medical service, patient satisfaction and loyalty with a focus on interpersonal-based medical service encounters and treatment effective-ness: a cross-sectional multicenter study of complementary and alternative medicine (CAM) hospitals. BMC Complement Altern Med. 17: 174. doi: 10.1186/s12906-017-1691-6.

Mulisa T, Tessema F dan Merga H (2017). Patients' satisfaction towards radiological service and associated factors in Hawassa University Teaching and referral hospital, Southern Ethiopia. BMC Health Services Research. 17:441 DOI 10.1186/s12913-017-2384-z

Murti B (2013). Desain dan Ukuran Sampel untuk Penelitian Kuantitatif dan Kualitatif di Bidang Kesehatan. Gadjah Mada University Press: Yogyakarta.

Olaleye, Olubukola A. Hamzat, Talhatu K. Oloso, Modinat O (2015). Perceived quality of physiotherapy services among informal caregivers of children with cerebral palsy in Ibadan, Nigeria. Journal of Pediatric Rehabilitation Medicine, 8(3): 227-234, 2015. DOI: 10.3233/PRM-150339.

Permenkes No. 80. (2013). Penyelenggaraan Pekerjaan dan Praktik Fisioterapis. Jakarta. 
Journal of Health Policy and Management (2017), 2(1): 69-80

https://doi.org/10.26911/thejhpm.2017.02.01.06

Revans R (2004). Researh Into Hospital Management and Organization. Health Services Research Study Section of the United States Public Health Service. New York.

Roland M, Dudley A (2015). How financial and reputational incentives can be used to improve medical care. Health Serv Res. 50(2): 2090-2115. doi: 10.1111/1475-6773.12419.

Schembri S (2014). Experiencing health care service quality: through patients' eyes. National Library of Medicine National Institutes of Health. DOI: 10.1071/AH14079.

Suryati C. (2005). Memahami Kemiskinan Secara Multidimensional. Fakultas Kesehatan Masyarakat dan Magister Ilmu Kesehatan Masyarakat Universitas Diponegoro, Semarang, Jawa Tengah. JMPK, 08(03).
Sutrisna B (1994). Pengantar Metoda Epidemiologi. Jakarta: PT Dian Rakyat.

Undang-Undang Sisdiknas No. 20 Tahun (2013). Sitem Pendidikan Nasional. Jakarta.

Wartawan IW (2012). Analisis Lama Hari Rawat Pasien yang Menjalani Pembedahan di Ruang Rawat Inap Bedah Kelas III RSUP Sanglah Denpasar Tahun 2011. Universitas Indonesia: Jakarta.

Zarei A, Arab M, Froushani A R, Rashidian A, Tabatabaei SMG (2012). Service quality of private hospitals: The Iranian Patients' perspective. BMC Health Services Research 2012, 12:31 Retrieved from http://www.biomedcentral.com/1472-6963/12/31. doi: 10.1186/1472-6963-12-31. 